\title{
Desulfovibrio putealis sp. nov., a novel sulfate-reducing bacterium isolated from a deep subsurface aquifer
}

\author{
Odile Basso, Pierre Caumette and Michel Magot \\ Université de Pau et des Pays de l'Adour, IBEAS, Laboratoire d'Ecologie Moléculaire, EA3525, \\ F-64013 PAU, France
}

Correspondence

Michel Magot

michel.magot@univ-pau.fr

\begin{abstract}
A novel sulfate-reducing bacterium was isolated from a well that collected water from a deep aquifer at a depth of $430 \mathrm{~m}$ in the Paris Basin, France. The strain, designated B7-43 ${ }^{\top}$, was made up of vibrioid cells that were motile by means of a single polar flagellum. Cells contained desulfoviridin. In the presence of sulfate, the following substrates were used as energy and carbon sources: lactate, pyruvate, malate, fumarate, ethanol, butanol, acetate/ $\mathrm{H}_{2}$ and glycine. Sulfite and thiosulfate were also used as electron acceptors in the presence of lactate. In the absence of electron acceptors, pyruvate, malate and fumarate were fermented. Optimal growth was obtained in $1 \mathrm{~g}$ $\mathrm{NaCl}{ }^{-1}$ and at $\mathrm{pH}$ 7. On the basis of 16S rRNA gene sequence analysis, the isolate was most closely related to members of the genus Desulfovibrio ( $90 \%$ similarity). It is thus proposed that strain B7-43 $\left(=\mathrm{DSM} 16056^{\top}=\right.$ ATCC BAA-905 ${ }^{\top}$ ) represents a novel species within this genus, Desulfovibrio putealis sp. nov.
\end{abstract}

During the last two decades, an increasing number of novel sulfate-reducing bacteria (SRB) have been isolated from a wide variety of environments such as fresh to saline and hypersaline waters or sediments, either from surface or subsurface habitats (Voordouw, 1995; Widdel \& Bak, 1992). Among them, strains of the genus Desulfovibrio are the most commonly isolated. Subsequently, a great number of novel Desulfovibrio species has been described during the last 10 years. Recently, several strains of SRB were isolated from a subsurface aquifer water sample. Among them, strain B7$43^{\mathrm{T}}$ was phylogenetically related, although distantly, to a large cluster of Desulfovibrio species. Considering its very low similarity to the closest existing species of the genus Desulfovibrio (less than $90 \%$ 16S rRNA gene sequence similarity), strain $\mathrm{B} 7-43^{\mathrm{T}}$ could possibly be described as a representative of a new genus of SRB. However, due to its phylogenetic position within the large Desulfovibrio cluster and its physiological traits, which are similar to those of most Desulfovibrio species, it is proposed that strain B7$43^{\mathrm{T}}$ should be classified in the genus Desulfovibrio. Therefore, because of its phylogenetic distance to the most closely related validly published members of the genus and its differing physiological traits, strain $\mathrm{B} 7-43^{\mathrm{T}}$ is proposed as a

Published online ahead of print on 23 July 2004 as DOI 10.1099/ ijs.0.63303-0.

Abbreviation: SRB, sulfate-reducing bacteria(-um).

The GenBank/EMBL/DDBJ accession number for the 16S rRNA gene sequence of $B 7-43^{\top}$ is $A Y 574979$. representative of a novel species, Desulfovibrio putealis sp. nov.

Strain B7 $-43^{\mathrm{T}}$ was isolated from a sample of deep subsurface water from the Paris Basin, France. Samples of formation water were aseptically collected at the wellhead under anoxic conditions as described previously (Basso et al., 2004). The total number of bacteria in a water sample (counted after staining with acridine orange) was $3 \times 10^{4}$ cells $\mathrm{ml}^{-1}$. Handling and enrichment cultures of sulfate-reducers were accomplished as described previously (Magot et al., 1992). The final salinity of the culture media was adjusted by addition of $\mathrm{NaCl}\left(1 \mathrm{~g} \mathrm{l}^{-1}\right)$ to mimic in situ conditions. Incubations were carried out at $30^{\circ} \mathrm{C}$, corresponding to the in situ temperature in the aquifer. Enrichment cultures were obtained by serial dilutions in Hungate tubes. The last positive tube was used for isolation by streaking on solid medium in Petri dishes under anaerobic conditions. Colonies obtained after 2 weeks incubation were picked and their isolation was repeated twice. The purity of strains was checked by phase-contrast microscopy. Strain B7- $43^{\mathrm{T}}$ was selected for detailed investigation. It was composed of vibrioid cells that were actively motile with a single polar flagellum. The cells were generally $2 \cdot 3-4 \cdot 1 \mu \mathrm{m}$ in length and $0.7 \mu \mathrm{m}$ wide. Cells occurred either singly or in pairs and stained Gram-negative.

To obtain a picture of the physiological properties of strain $\mathrm{B} 7-43^{\mathrm{T}}$, the following tests were carried out: utilization of carbon and energy sources, utilization of a variety of 
electron acceptors, fermentative growth tests and determination of temperature, $\mathrm{pH}$ and salinity optima (Magot et al., 1992; Pfennig et al., 1981; Tardy-Jacquenod et al., 1996; Widdel \& Bak, 1992). All tests were performed in triplicate. Strain $\mathrm{B} 7-43^{\mathrm{T}}$ was a strictly anaerobic micro-organism; no growth was observed when it was incubated in the presence of air. The substrates tested as energy and carbon sources are listed in Table 1. Strain B7-43 ${ }^{\mathrm{T}}$ used the following substrates as energy and carbon sources in the presence of sulfate as electron acceptor: lactate, pyruvate, malate, fumarate, ethanol, butanol, glycine and acetate $/ \mathrm{H}_{2}$. Acetate was produced from lactate oxidation. No growth was observed on acetate, propionate, butyrate, benzoate, succinate, pyruvate, citrate, methanol, glycerol, glucose, fructose, alanine, cysteine, glutamate, aspartate, formate, toluene, propanol or $\mathrm{H}_{2} / \mathrm{co}_{2}$. The spectrum of cell extracts exhibited the characteristic absorption band of desulfoviridin at $631 \mathrm{~nm}$ (Postgate, 1956). Strain $\mathrm{B} 7-43^{\mathrm{T}}$ grew at $20-40^{\circ} \mathrm{C}$, with optimal growth at $30^{\circ} \mathrm{C}$. No growth was observed at 15 or $45^{\circ} \mathrm{C}$. Strain $\mathrm{B} 7-43^{\mathrm{T}}$ was unable to grow in $\mathrm{NaCl}$ concentrations higher than $6 \mathrm{~g} \mathrm{l}^{-1}$. Optimal growth was observed between 0 and $1 \mathrm{~g} \mathrm{NaCl}^{-1} \cdot \mathrm{pH} \mathrm{7 \cdot 0} \mathrm{was} \mathrm{optimal} \mathrm{for} \mathrm{growth,} \mathrm{but} \mathrm{the}$ isolate grew well between $\mathrm{pH} 6 \cdot 25$ and $7 \cdot 5$. Under optimal conditions, with lactate as electron donor and sulfate as

Table 1. Characteristics that can discriminate between strain $B 7-43^{\top}$ and other related Desulfovibrio species

Taxa: 1, Desulfovibrio putealis $\mathrm{B} 7-43^{\mathrm{T}} ; 2$, D. vulgaris; 3, D. alcoholivorans; 4, D. gabonensis; 5, D. longus; 6, D. sulfodismutans; 7, D. profundus; 8, D. fructosivorans; 9, D. magneticus; 10, D. burkinensis, 11, sulfate-reducing bacterium F1-7b. Data were taken from Postgate \& Campbell (1966), Qatibi et al. (1991), Tardy-Jacquenod et al. (1996), Magot et al. (1992), Bak \& Pfennig (1987), Bale et al. (1997), Ollivier et al. (1988), Sakaguchi et al. (2002), Ouattara et al. (1999) and Wind et al. (1999). The following substrates were also tested but were not used by strain $\mathrm{B} 7-43^{\mathrm{T}}$ with sulfate as electron acceptor: butyrate, benzoate, succinate, citrate, methanol, glucose, fructose, alanine, glutamate, aspartate, formate, toluene and propanol. +, Positive test reaction; $(+)$, weak test reaction; -, negative test reaction; ND, not determined.

\begin{tabular}{|c|c|c|c|c|c|c|c|c|c|c|c|}
\hline Characteristic & 1 & 2 & 3 & 4 & 5 & 6 & 7 & 8 & 9 & 10 & 11 \\
\hline Morphology & Vibrio & Vibrio & $\begin{array}{l}\text { Curved } \\
\text { rods }\end{array}$ & $\begin{array}{l}\text { Curved } \\
\text { rods }\end{array}$ & $\begin{array}{l}\text { Long, thin } \\
\text { vibrios }\end{array}$ & Curved cells & Vibrio & $\begin{array}{l}\text { Curved } \\
\text { rods }\end{array}$ & $\begin{array}{l}\text { Vibrio- } \\
\text { shaped }\end{array}$ & $\begin{array}{l}\text { Curved } \\
\text { rods }\end{array}$ & $\begin{array}{c}\text { Curved } \\
\text { rods }\end{array}$ \\
\hline Cell diameter $(\mu \mathrm{m})$ & $0 \cdot 7$ & $0 \cdot 5-1 \cdot 0$ & $0 \cdot 7-0 \cdot 9$ & $0 \cdot 4$ & $0 \cdot 4-0 \cdot 5$ & $0 \cdot 75$ & $0 \cdot 5-1$ & $0 \cdot 5-0 \cdot 7$ & 1 & $0 \cdot 8-1 \cdot 2$ & $0 \cdot 8-1 \cdot 2$ \\
\hline Cell length $(\mu \mathrm{m})$ & $2 \cdot 3-4 \cdot 1$ & $3 \cdot 0-5 \cdot 0$ & $2 \cdot 8-3 \cdot 2$ & $2-4$ & $5 \cdot 0-10 \cdot 0$ & $2 \cdot 5-3 \cdot 5$ & $1-2$ & $2-4$ & $3-5$ & $2 \cdot 2-3 \cdot 1$ & $2 \cdot 1-2 \cdot 8$ \\
\hline Salinity range $\left(\mathrm{g} \mathrm{l}^{-1}\right)$ & $0-6$ & & $0-2$ & $10-170$ & $0-80$ & Maxima of 20 & $2-100$ & $0-40$ & $0-5$ & $0-10$ & ND \\
\hline Salinity optimum $\left(\mathrm{g}^{-1}\right)$ & $0-1$ & 0 & $0 \cdot 75$ & $50-60$ & $10-20$ & 14 & $6-80$ & 0 & 0 & 0 & ND \\
\hline $\mathrm{G}+\mathrm{C}$ content $(\mathrm{mol} \%)$ & $57 \cdot 8$ & 61 & $64 \cdot 5 \pm 0 \cdot 3$ & $59 \cdot 5$ & $62 \cdot 3$ & $64 \cdot 1$ & 53 & $64 \cdot 13$ & 66 & 67 & ND \\
\hline \multicolumn{12}{|l|}{ Electron donors: } \\
\hline $\mathrm{H}_{2}+\mathrm{CO}_{2}$ & - & & + & - & - & & - & + & - & - & + \\
\hline $\mathrm{H}_{2}+$ acetate & $(+)$ & & + & + & + & - & + & + & - & + & + \\
\hline Lactate & + & + & + & + & + & + & + & + & + & + & + \\
\hline Pyruvate & + & + & + & + & + & - & + & + & + & + & + \\
\hline Malate & + & - & + & + & - & - & - & + & + & + & - \\
\hline Fumarate & + & & + & + & - & - & - & + & + & + & $(+)$ \\
\hline Acetate & - & - & - & - & - & - & + & - & - & - & - \\
\hline Propionate & - & & - & - & - & - & - & - & - & - & - \\
\hline Ethanol & $(+)$ & & + & + & - & + & - & $(+)$ & + & + & + \\
\hline Butanol & $(+)$ & & + & $(+)$ & - & + & & & ND & + & - \\
\hline Glycerol & - & & + & - & - & & & + & + & + & $\mathrm{ND}$ \\
\hline Cysteine & - & & ND & - & - & & - & - & ND & ND & ND \\
\hline Glycine & $(+)$ & & $\mathrm{ND}$ & & & & - & - & - & $\mathrm{ND}$ & $\mathrm{ND}$ \\
\hline \multicolumn{12}{|l|}{ Fermentation: } \\
\hline Pyruvate & + & + & + & + & - & & & + & + & + & \\
\hline Malate & + & & - & + & - & & & + & - & + & \\
\hline Lactate & - & & & & - & & + & - & - & & \\
\hline Fumarate & + & & + & & & & & + & - & + & \\
\hline \multicolumn{12}{|l|}{ Electron acceptors: } \\
\hline Sulfate & + & + & + & + & + & - & + & + & + & + & + \\
\hline Sulfite & + & & + & + & + & + & + & + & - & + & + \\
\hline Thiosulfate & + & & + & + & + & + & + & + & + & + & + \\
\hline Sulfur & - & & + & + & + & - & - & + & + & + & $(+)$ \\
\hline Nitrate & - & & - & - & - & - & + & - & ND & - & $(+)$ \\
\hline Fumarate & + & & ND & ND & + & - & $(+)$ & & + & + & - \\
\hline
\end{tabular}


electron acceptor, the maximum growth rate of strain B7- $43^{\mathrm{T}}$ was $0 \cdot 115 \mathrm{~h}^{-1}$ and the doubling time was $6 \mathrm{~h}$.

The $\mathrm{G}+\mathrm{C}$ content of strain $\mathrm{B} 7-43^{\mathrm{T}}$ DNA was determined by HPLC at the Identification Service of the DSMZ (Deutsche Sammlung von Mikroorganismen und Zellkulturen, Braunschweig, Germany). The $\mathrm{G}+\mathrm{C}$ content of the DNA was $57 \cdot 8 \mathrm{~mol} \%$.

The 16S rRNA gene of strain $B 7-43^{\mathrm{T}}$ was amplified and its sequence was determined and analysed as described previously (Maidak et al., 2001; Tardy-Jacquenod et al., 1996; Weisburg et al., 1991). A search for related sequences was performed using the GenBank and EMBL databases and the BLAST (Altschul et al., 1990) and FASTA (Pearson \& Lipman, 1988) software packages.

A total of $1498 \mathrm{nt}$ of the 16S rRNA gene sequence of strain $\mathrm{B} 7-43^{\mathrm{T}}$ was determined. The sequence was aligned with representatives of the $\delta$-Proteobacteria from the family 'Desulfovibrionaceae'. Phylogenetic analysis revealed that strain B7-43 $3^{\mathrm{T}}$ was included in the wide cluster of the genus Desulfovibrio. The phylogenetic tree obtained using the neighbour-joining method is shown in Fig. 1. Strain B7-43 clustered with Desulfovibrio sulfodismutans (Bak \& Pfennig,
1987) with a similarity of $90 \cdot 7 \%$ and Desulfovibrio alcoholivorans (Qatibi et al., 1991) with a similarity of $90 \cdot 6 \%$. Its closest relative was $\mathrm{F} 1-7 \mathrm{~b}(99 \cdot 7 \%$ similarity), a partially described SRB isolated from rice field soil (Wind et al., 1999). This high level of similarity suggested that these two strains may belong to the same species. Unfortunately, strain F1-7b has been lost (R. Conrad, personal communication) and further comparison of their physiological characters or DNA-DNA hybridization experiments cannot be achieved.

Strain $B 7-43^{\mathrm{T}}$ differed from $D$. sulfodismutans by its ability to grow with pyruvate, malate and fumarate as electron donors. Unlike D. sulfodismutans, it is not halotolerant (Table 1). It differed from D. alcoholivorans by its inability to use glycerol as an electron donor and its ability to ferment malate. Strain $\mathrm{B} 7-43^{\mathrm{T}}$ also differed from its closest relative, strain F1-7b, in utilization of different energy and carbon sources (Table 1), such as malate, butanol or $\mathrm{H}_{2} / \mathrm{CO}_{2}$.

Although strain $\mathrm{B} 7-43^{\mathrm{T}}$ was phylogenetically distant from known Desulfovibrio species, suggesting that it could even be a member of a new genus, its physiological characteristics are essentially the same as those displayed by Desulfovibrio species. Although $\mathrm{B} 7-43^{\mathrm{T}}$ was a typical freshwater isolate, with an optimal salinity for growth of $1 \mathrm{~g} \mathrm{NaCll}^{-1}$ or less, its

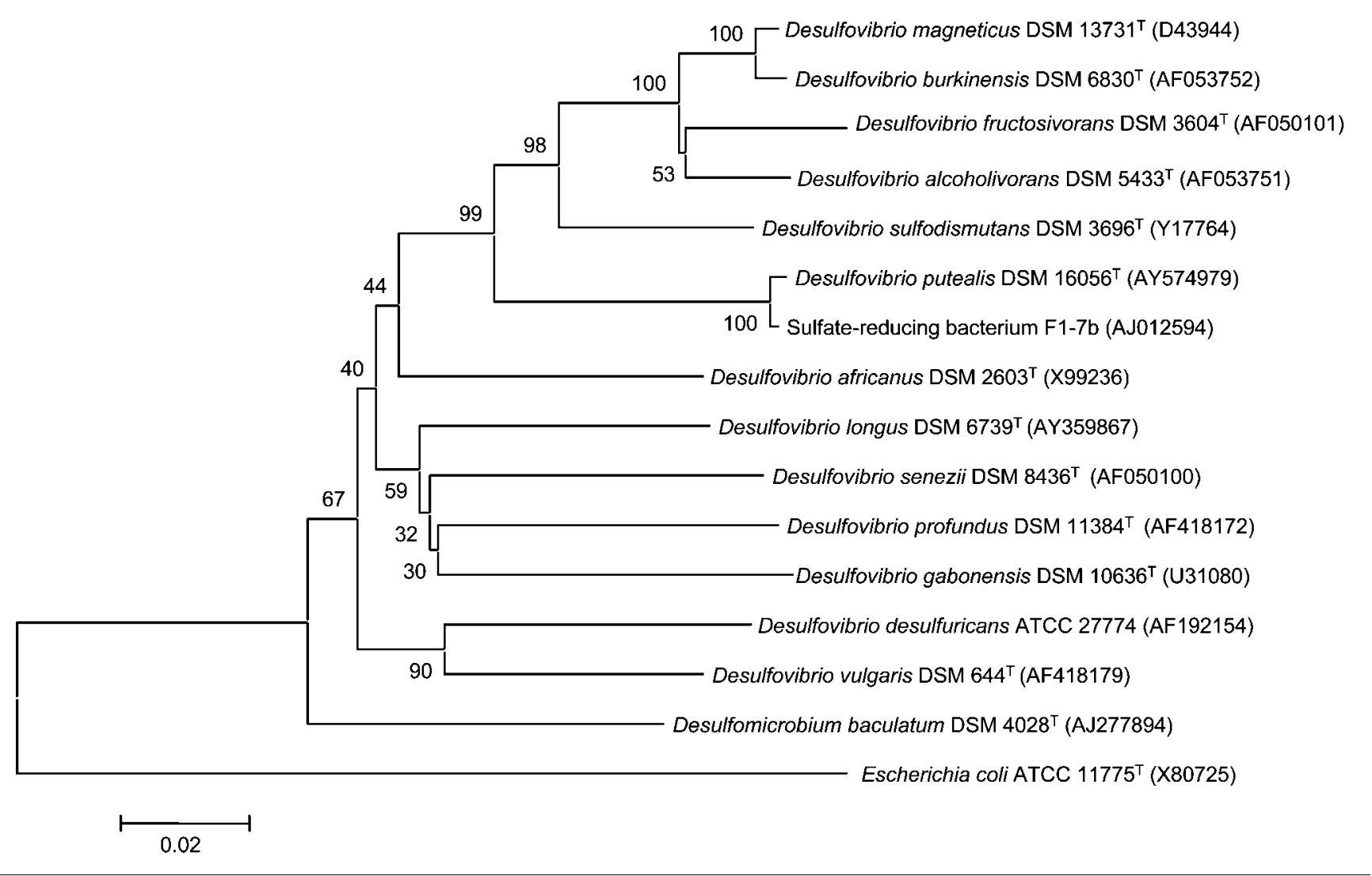

Fig. 1. Phylogenetic tree based on a comparison of the $16 \mathrm{~S}$ rRNA gene sequences of Desulfovibrio putealis $B 7-43^{\top}$ and selected species of the $\delta$-Proteobacteria. The tree was constructed by the neighbour-joining method and rooted using Escherichia coli as an outgroup. Bootstrap values (expressed as percentages) for 1000 replicates are shown. Bar, $2 \mathrm{nt}$ changes per $100 \mathrm{nt}$. 
DNA G + C content of $57 \cdot 8 \mathrm{~mol} \%$ was closer to that of most halophilic Desulfovibrio species (46.1-62.0 mol\%) such as Desulfovibrio profundus (Bale et al., 1997) or Desulfovibrio gabonensis (Tardy-Jacquenod et al., 1996). Generally, freshwater isolates such as D. sulfodismutans have a higher $\mathrm{G}+\mathrm{C}$ content (62-67 mol\%) (Table 1). Strain B7-43 ${ }^{\mathrm{T}}$ was also phylogenetically distinct from Desulfovibrio species isolated from the deep subsurface, e.g. D. profundus, Desulfovibrio longus (Magot et al., 1992) and D. gabonensis, and by its inability to grow at $\mathrm{NaCl}$ concentrations above $6 \mathrm{~g} \mathrm{l}^{-1}$. On the basis of its physiological and phylogenetic properties compared with those of other members of the genus Desulfovibrio, it is proposed that strain $\mathrm{B} 7-43^{\mathrm{T}}$ represents a novel species, Desulfovibrio putealis sp. nov.

\section{Description of Desulfovibrio putealis sp. nov.}

Desulfovibrio putealis (pu.te.a'lis. L. adj. putealis from a well).

Vibrioid cells, $2 \cdot 3-4 \cdot 1 \times 0 \cdot 7 \mu \mathrm{m}$. Gram-negative. Motile by means of a single polar flagellum. Optimum growth occurs at $30^{\circ} \mathrm{C}$ and $\mathrm{pH} 7 \cdot 0$. Grows in $0-6 \mathrm{~g} \mathrm{NaCl} \mathrm{l}^{-1}$, with optimum growth at $1 \mathrm{~g} \mathrm{NaCl}^{-1}$. Strictly anaerobic. Able to use sulfate, sulfite and thiosulfate, with production of sulfide. Nitrate is not used as an electron acceptor. Substrates that are oxidized by anaerobic respiration of a sulfate compound are $\mathrm{H}_{2}$, lactate, pyruvate, malate, fumarate, ethanol, butanol and glycine. $\mathrm{H}_{2}$ is only utilized in the presence of acetate. Pyruvate, fumarate and malate are fermented. Acetate, butyrate, benzoate, succinate, citrate, methanol, glucose, fructose, alanine, glutamate, aspartate, formate, toluene and propanol are not utilized. Desulfoviridin is present.

The type strain is $\mathrm{B} 7-43^{\mathrm{T}}$ (=DSM $16056^{\mathrm{T}}=$ ATCC BAA$905^{\mathrm{T}}$ ), which was isolated from a water-producing well in France. The DNA $\mathrm{G}+\mathrm{C}$ content of the type strain is $57 \cdot 8 \mathrm{~mol} \%$.

\section{Acknowledgements}

We greatly thank M. L. Fardeau (IRD, Marseille, France) for analysis of the terminal end products of lactate oxidation.

\section{References}

Altschul, S. F., Gish, W., Miller, W., Myers, E. W. \& Lipman, D. J. (1990). A basic local alignment search tool. J Mol Biol 215, 403-410.

Bak, F. \& Pfennig, N. (1987). Chemolithotrophic growth of Desulfovibrio sulfodismutans sp. nov. by disproportion of inorganic sulfur compounds. Arch Microbiol 147, 184-189.

Bale, S. J., Goodman, K., Rochelle, P. A., Marchesi, J. R., Fry, J. C., Weightman, A. J. \& Parkes, R. J. (1997). Desulfovibrio profundus sp. nov., a novel barophilic sulfate-reducing bacterium from deep sediment layers in the Japan Sea. Int J Syst Bacteriol 47, 515-521.

Basso, O., Lascourrèges, J.-F., Jarry, M. \& Magot, M. (2004). The effect of cleaning and disinfecting the sampling well on the microbial communities of deep subsurface water samples. Environ Microbiol OnlineEarly doi:10.1111/j.1462-2920.2004.00660.x.

Magot, M., Caumette, P., Desperrier, J. M., Matheron, R., Dauga, C., Grimont, F. \& Carreau, L. (1992). Desulfovibrio longus sp. nov., a sulfate-reducing bacterium isolated from an oil-producing well. Int J Syst Bacteriol 42, 398-403.

Maidak, B. L., Cole, J. R., Lilburn, T. G. \& 7 other authors (2001). The RDP-II (Ribosomal Database Project). Nucleic Acids Res 29, 173-174.

Ollivier, B., Cord-Ruwisch, R., Hatchikian, E. C. \& Garcia, J. L. (1988). Characterization of Desulfovibrio fructosovorans sp. nov. Arch Microbiol 149, 447-450.

Ouattara, A. S., Patel, B. K. C., Cayol, J.-L., Cuzin, N., Traore, A. S. \& Garcia, J.-L. (1999). Isolation and characterization of Desulfovibrio burkinensis sp. nov. from an African ricefield, and phylogeny of Desulfovibrio alcoholivorans. Int J Syst Bacteriol 49, 639-643.

Pearson, W. \& Lipman, D. (1988). Improved tools for biological sequence comparison. Proc Natl Acad Sci U S A 85, 2444-2448.

Pfennig, N., Widdel, F. \& Trüper, H. G. (1981). The dissimilatory sulfate-reducing bacteria. In The Prokaryotes, vol. 1, pp. 926-940. Edited by M. P. Starr, H. Stolp, H. G. Trüper, A. Balows \& H. G. Schlegel. Berlin: Springer.

Postgate, J. R. (1956). Cythochrome $c_{3}$ and desulphoviridin; pigments of the anaerobe Desulfovibrio desulphuricans. J Gen Microbiol 14, 545-572.

Postgate, J. R. \& Campbell, L. L. (1966). Classification of Desulfovibrio species, the nonsporulating sulfate-reducing bacteria. Bacteriol Rev 30, 732-738.

Qatibi, A. I., Nivière, V. \& Garcia, J. L. (1991). Desulfovibrio alcoholovorans sp. nov., a sulfate-reducing bacterium able to grow on glycerol, 1,2- and 1,3-propanediol. Arch Microbiol 155, 143-148.

Sakaguchi, T., Arakaki, A. \& Matsunaga, T. (2002). Desulfovibrio magneticus sp. nov., a novel sulfate-reducing bacterium that produces intracellular single-domain-sized magnetite particles. Int J Syst Evol Microbiol 52, 215-221.

Tardy-Jacquenod, C., Magot, M., Laigret, F., Kaghad, M., Patel, B. K. C., Guezennec, J., Matheron, R. \& Caumette, P. (1996). Desulfovibrio gabonensis sp. nov., a new moderately halophilic sulfate-reducing bacterium isolated from an oil pipeline. Int J Syst Bacteriol 46, 710-715.

Voordouw, G. (1995). The genus Desulfovibrio: the centennial. Appl Environ Microbiol 61, 2813-2819.

Weisburg, W. G., Barns, S. M., Pelletier, D. A. \& Lane, D. J. (1991). $16 \mathrm{~S}$ ribosomal DNA amplification for phylogenetic study. J Bacteriol 173, 697-703.

Widdel, F. \& Bak, F. (1992). Gram-negative mesophilic sulfatereducing bacteria. In The Prokaryotes, 2nd edn, pp. 3353-3378. Edited by A. Balows, H. G. Trüper, M. Dworkin, W. Harder \& K.-H. Schleifer. New York: Springer.

Wind, T., Stubner, S. \& Conrad, R. (1999). Sulfate-reducing bacteria in rice field soil and on rice roots. Syst Appl Microbiol 22, 269-279. 